\title{
ANALISIS KEPUASAN CUSTOMER MENGGUNAKAN PENDEKATAN MODEL KANO DAN APLIKASI QUALITY FUNCTION DEPLOYMENT (QFD) DAN TEORIYA RESHENIYA IZOBRETATELSKIKH ZADATCH (TRIZ) UNTUK MENINGKATKAN MUTU LAYANAN JASA PERBANKAN
}

\author{
(Studi Kasus di PT. Bank Rakyat Indonesia Kantor Bangli)
}

\author{
Mardiki Supriadi \\ ${ }^{1}$ Program Studi Teknik Industri, Fakultas Teknik, Universitas Mahendradatta \\ Jl. Ken Arok No.12, Peguyangan, Denpasar, Bali 80115 \\ Email: mardiki@yahoo.co.id
}

\begin{abstract}
Abstrak- Persaingan antar lembaga perbankan yang terjadi pada saat ini membuat nasabah semakin hati-hati dalam memilih lembaga perbankan yang dipercaya. Apabila nasabah mendapatkan pelayanan yang tidak sesuai dengan yang diinginkan maka pihak manajemen bisa kehilangan kepercayaan nasabah. Pada akhirnya nasabah akan mencari lembaga perbankan lain. Hal ini merupakan suatu kerugian bagi pihak manajemen. Pihak manajemen seharusnya melakukan perbaikan kualitas pelayanan untuk terus mendapatkan kepercayaan nasabah dan dapat terus berkembang. Oleh karena itu lembaga perbankan perlu membuat Standar Pelayanan Minimal penyelenggaraan layanan perbankan yang sesuai dengan keinginan nasabah. Penelitian ini bertujuan untuk mengetahui standart pelayanan yang sesuai dengan keinginan nasabah serta menyusun prioritas perbaikan kualitas pelayanan yang seharusnya diberikan kepada nasabah bank BRI kantor Bangli. Pendekatan yang dilakukan adalah metode Kano untuk mengkategorikan atribut keinginan nasabah kedalam kategori Kano, metode Quality Function Deployment (QFD) untuk menerjemahkan keinginan nasabah menjadi apa yang harus dihasilkan oleh pihak manajemen bank dan metode Teoriya Resheniya Izobretatelskikh Zadatch (TRIZ) untuk memperbaiki respon teknis yang saling berkontadiksi. Penelitian ini menggunakan kuesioner sebagai instrumen penelitian. Melalui hasil penyebaran kuesioner diketahui 10 variabel keinginan yang dibutuhkan oleh nasabah dan dikelompokkan berdasarkan 3 dimensi Kano. Hasil pengkategorian atribut dengan Kano menunjukkan bahwa masih ada atribut yang terkategori must be dan one dimensional, artinya masih perlu bentuk perbaikan dari pihak manajemen bank. Dari pembentukan matriks House of Quality (HOQ) diketahui bahwa variabel "dokumentasi dan informasi" menjadi prioritas pertama dalam upaya perbaikan dengan nilai tingkat kepentingan tertinggi yakni 19,58\% dan tingkat kesulitan 13,10\%.
\end{abstract}

Kata Kunci : Kano, quality function deployment (QFD), theoriya resheniya izobretatelskikh zadatch (TRIZ)

Abstract- The current competition among banking institutions has made customers more careful in choosing trusted banking institutions. If the customer gets a service that is not in accordance with what is desired, the management can lose customer confidence. In the end, customers will look for other banking institutions. This is a loss for management. Management should improve service quality to continue to gain customer trust and can continue to grow. Therefore, banking institutions need to create a Service Standard for the minimum implementation of banking services that are in accordance with the wishes of customers. This study aims to determine the standard of service that is in accordance with the wishes of customers and to prioritize the quality of service improvements that should be given to BRI bank customers at the Bangli office. The approach taken is the Kano method to categorize customer desires into the Kano category, the Quality Function Deployment (QFD) method to translate customer desires into what must be produced by bank management and the Resheniya Izobretatelskikh Zadatch (TRIZ) Theory method to improve mutual technical responses contradict. This study uses a questionnaire as a research instrument. Through the results of 
questionnaires it is known that 10 desires are needed by customers and are grouped based on 3 dimensions of Canoe. The results of categorizing attributes with Kano show that there are still categorized attributes as must be and one dimensional, meaning that there still needs to be a form of improvement from the management of the bank. From the formation of the House of Quality (HOQ) matrix, it is known that the variable "documentation and information" is the first priority in efforts to improve with the highest importance level of $19.58 \%$ and difficulty level $13.10 \%$.

Keywords: Canoeing, quality function deployment (QFD), theoriya resheniya izobretatelskikh zadatch (TRIZ)

\section{PENDAHULUAN}

Bank Rakyat Indonesia (BRI) kantor Bangli merupakan salah satu perusahaan perbankan berbadan usaha milik negara yang berada di Bangli Provinsi Bali. Sebagai perusahaan perbankan yang bertaraf nasional, tentulah BRI harus mampu memberikan pelayanan yang serba memuaskan baik itu dalam bentuk produk maupun jasa. Namun, hal inilah yang masih belum dapat dipenuhi oleh manajemen perusahaan.

Masalah yang muncul yakni kurangnya perhatian pihak manajemen akan pengembangan terbaru yang berkenaan dengan peningkatan kualitas pelayanan nasabah. Selama ini standart kualitas yang digunakan tidak pernah dilakukan penyesuaian dengan kondisi nasabah di daerah Bangli. Standart pelayanan yang digunakan adalah standart pelayanan yang dibuat oleh pihak bank BRI sentral tanpa ada penyesuaian, sehingga perlu dibuat suatu standart pelayanan baru yang disesuaikan dengan keinginan nasabah yang berada di daerah Bangli.

Nasabah akan lebih selektif dalam memilih bank kepercayaannya untuk bertransaksi, sehingga bank yang memberikan kepuasan tertinggilah yang akan dipilih nasabah. Dalam prespektifnya, konsumen cenderung memperhatikan nilai-nilai kepuasan yang dirasakannya, sebagai konsekuensinya setiap usaha penyediaan layanan jasa juga perlu memperhatikan kualitas layanan yang diberikan sehingga mampu memenuhi tuntunan nasabah. Hal ini bila diperhatikan akan menuntut kita pada suatu faktor penting diluar kekuatan modal yang dibutuhkan untuk menghidupi bank tersebut, yakni kepercayaan nasabah terhadap bank, pelayanan terhadap nasabah yang nota benenya adalah customer bank merupakan satu dari sekian banyak faktor yang harus diperhatikan demi kemajuan bank.

Sebagai upaya untuk memenuhi harapan dan kebutuhan Nasabah, maka dilakukan penelitian dengan menggunakan model KANO sera kombinasi metode Quality Function Development (QFD) dan Teoriya Resheniya Izobretatelskikh Zadatch (TRIZ). Pendekatan Model KANO digunakan untuk menentukan atribut mana yang menjadi keunggulan dan kelemahan berdasarkan dimensi service quality sesuai dengan keinginan konsumen terhadap suatu pelayanan. Kemudian TRIZ digunakan untuk memperbaiki kinerja dengan mereduksi kontradiksi teknis ataupun fisik dari respon teknis.

\section{METODE PENELITIAN}

Penelitian ini dilakukan di Bank Rakyat Indonesia (BRI) Kantor Bangli yang di provinsi Bali. Adapun pelaksanaan penelitian di lembaga perbankan ini karena perusahaan dalam proses peningkatan kualitas layanan jasa perbankan. Penelitian dilakukan selama 1 bulan. Jenis penelitian ini adalah penelitian deskriptif yaitu suatu jenis penelitian yang bertujuan untuk mendeskripsikan secara sistematik, faktual dan akurat tentang faktafakta dan sifat-sifat suatu objek atau populasi tertentu. Penelitian ini juga merupakan penelitian survei yang merupakan bagian dari penelitian deskriptif yaitu penelitian yang dilakukan untuk memperoleh fakta-fakta dari gejala yang ada dan mencari keterangan 
secara faktual untuk mendapatkan kebenaran. Yang menjadi objek dalam penelitian ini adalah segala bentuk pelayanan jasa perbankan yang dilakukan oleh manajemen Bank BRI Kantor Bangli. Adapun penelitian ini dikonsentrasikan pada perbaikan kualitas pelayanan jasa perbankan di Bank BRI Kantor Bangli.

\section{HASIL DAN PEMBAHASAN}

Penyebaran kuesioner yang telah dilakukan menghasilkan beberapa hal yang berguna bagi pihak manajemen bank di antaranya:

1. Dapat mengetahui kebutuhan-kebutuhan nasabah terhadap jasa perbankan bank BRI kantor Bangli.

2. Dapat mengetahui kategori-kategori berbagai kebutuhan lebih spesifik dalam menilai kualitas tingkat pelayanan perbankan bank BRI kantor Bangli.

Berdasarkan data yang diperoleh dari kuesioner, diketahui bahwa terdapat sepuluh variabel kebutuhan nasabah terhadap pelayanan perbankan. Keseluruhan dari sepuluh variabel pelayanan tersebut dikelompokkan ke dalam tiga dimensi kualitas pelayanan jasa yang menggunakan model KANO, yakni musbe needs, One dimensional, dan attractive (Valerie A Zeithaml,dkk.,1990). Kuesioner yang telah disebarkan untuk lebih lanjut maka dapat dilakukan uji validitas dan reliabilitas. Hasil perhitungan validitas data kepentingan dan kuesioner kano diketahui bahwa seluruh variabel dinyatakan valid dikarenakan koefisien korelasi Spearman bernilai lebih besar dari nilai $r$ tabel. Hal ini berarti bahwa kuesioner yang digunakan sebagai instrumen pengumpulan data telah benar dan tidak perlu diganti. Dari hasil perhitungan reliabilitas data kepentingan dan kano juga didapatkan hasil yang reliabel. Hal ini dilihat dari nilai koefisiennya yang lebih besar dari nilai batas koefisien reliabel untuk penilaian reliabilitas kuesioner yakni sebesar 0,6 . Hal ini berarti bahwa keseluruhan data yang diperoleh dari hasil penyebaran kuesioner telah layak digunakan dan diolah lebih lanjut.
Hasil pengolahan data dapat memberikan suatu gambaran mengenai kebutuhan dan kepentingan nasabah terhadap kualitas pelayanan bank BRI kantor Bangli. Sejalan dengan itu, maka dapat juga diketahui kategori dimensi yang sesuai dengan keinginan nasabah terhadap pelayanan tersebut. Sehingga bentuk perbaikan akan lebih spesifik dilakukan dalam memenuhi kebutuhan nasabah sesuai dengan konsep yang diberikan oleh metode Kano. Berdasarkan hasil perhitungan model kano, didapatkan bahwa pelayanan di bank BRI kantor Bangli perlu dilakukan perbaikan sesuai dengan kategorinya. Hal ini berarti berdasarkan persepsi nasabah, ada beberapa atribut pelayanan yang belum memenuhi apa yang menjadi kebutuhan/ keinginan nasabah. Atribut-atribut tersebut adalah atribut yang terkategori must be dalam kategori kano. Kategori must be adalah kategori kebutuhan dasar yang harus dipenuhi pihak manajemen sehingga apabila kinerja atribut yang terkategori must be buruk maka nasabah akan langsung merasakan dampak tersebut dan akan memberikan penilaian buruk terhadap kinerja pelayanan perbankan bank BRI Bangli. Untuk perbaikan yang lebih efektif dan efisien terhadap penggunaan sumber daya yang ada maka prioritas perbaikan dilakukan berdasarkan kategori-kategori Kano tersebut.

Hasil penyebaran kuesioner menghasilkan tingkat kepentingan suatu variabel pelayanan terhadap variabel pelayanan lainnya. Hasilnya dapat dilihat bahwa atribut yang memiliki tingkat kepentingan paling tinggi adalah masalah Ketelitian, kesigapan, dan Kecepatan pelayanan $(0,1289)$. Sesuai dengan pembahasan analisis kano diatas yang mengatakan bahwa masalah peraturan tersebut ada dalam kategori must be (kebutuhan dasar) maka perlu dilakukan suatu bentuk perbaikan terhadap masalah peraturan agar memberikan kinerja yang tinggi terhadap pelayanan.

Spesific Problem merupakan dasar permasalahan yang terjadi, yakni hubungan karakteristik pelayanan yang memiliki hubungan negatif. Terdapat empat karakteristik pelayanan yang memiliki 
hubungan negatif. Pada spesific problem ini juga dibedakan atas 2 bagian yaitu usefull feature dan harmfull feature. Usefull feature merupakan suatu karakteristik pelayanan yang ingin diperbaiki namun menimbulkan masalah pada karakteristik pelayanan yang lain. Harmfull feature merupakan suatu karakteristik pelayanan yang menjadi lebih buruk ketika masalah tersebut diselesaikan.

\section{KESIMPULAN}

1. Konsumen menginginkan sepuluh atribut pelayanan yang diberikan oleh manajemen bank BRI kantor cabang Bangli yaitu peraturan mudah dipahami, persyaratan tidak berbelit belit, pelayanan yang teliti, cepat dan sigap, simpanan dijamin pemerintah, layanan perbankan elektronik, banking hall yang nyaman, tempat parkir, kemudahan administrasi dan bunga yang kompetitif.

2. Menurut kategori kano peraturan mudah dipahami, kemudahan administrasi, dan pinjaman bunga ringan merupakan kategori must be. Persyaratan tidak berbelit-belit, kecepatan pelayanan, banking hall yang nyaman, dan bunga yang kompetitif merupakan kategori attractive, sedangkan simpanan dijamin pemerintah dan tersedianya parkir nasabah merupakan kategori one dimensional.

3. Prioritas tingkat kepentingan karakteristik pelayanan yang perlu perbaikan adalah masalah dokumentasi dan informasi karena memiliki bobot tingkat kepentingan yang terbesar yaitu $19,58 \%$ dan tingkat kesulitan $13,10 \%$.

4. Perbaikan pelayanan yang dilakukan berdasarkan TRIZ adalah menggunakan teknologi yang ramah lingkungan, membatasi kriteria transaksi online, merubah mekanisme berdasarkan nominal transaksi, dan segmentasi terhadap transaksi layanan elektronik.

\section{DAFTAR PUSTAKA}

A. Theresia. 2001. Integrating Servqual and Kano's Model into QFD for service exellence Development. MCB university Press

Agung Yuniarto. Hari. 2006. Pengukuran dan Peningkatan Kinerja Perusahaan
Dalam Kerangka Business Process re-engineering (BPR) Dengan Menggunakan Metode Quality Function Deployment (QFD). Volume 3, Nomor 2, Edisi Mei 2006. ISSN 1693-704X

Altuntas, Serkhan. 2012. An Approach Based on TRIZ Methodology and Servqual Scale to Improve the Quality of Health-Care service. Bayburt University

Anindya Lakshitta \& Sritomo Wignjosoebroto. Jurnal of Perancangan Jumbo Bag Dengan Pendekatan Qfd Dan Triz Dalam Upaya Peningkatan Produktivitas (Studi Kasus : Bongkar Muat Pupuk Di Pt. Petrokimia Gresik). Intitut Teknologi Sepuluhu Nopember Surabaya

Buchori, Herry Achmad dan Jasmine Saladin. 2006. Dasar-dasar Pemasaran Bank. Linda Karya Chi-Kuang Chen †,dkk. Journal of Developing a TRIZ-Based Service System Innovation Model for Aging in Place Chiou chun chuang. Integrating Kano Model and TRIZ for Service Innovation of Telehealthcare. World academy of science

Cohen, Lou. 1995.Quality Function Deployment, How to Make QFD Work For You. New York :AddisonWesley Publishing Company.

E.Mulyasa. Implementasi Kurikulum Tingkat Satuan Pendidikan. Bumi Aksara. Jakarta. 2009

Ghozali, Imam. 2002. Aplikasi Analisis Multivariat dengan Program SPSS. Semarang: Badan Penerbit Universitas Dipenogoro.

Ginting, Rosnani , 2010. Perancangan Produk . Graha IImu. Yogyakarta.

Hartono Jogiyanto. 2005. Sistem Teknonogi Informasi. Yogyakarta : Andi

Kementrian Pendidikan Nasional dan Kementrian Agama. Buku Materi Pelatihan Sekolah/Madrasah. Peningkatan Manajemen Melalui Penguatan Tata Kelola dan Akuntabilitas di Sekolah/Madrasah.

Khamseh, Arshadi. 2011. Integrating Kano's Model into Quality Function Deployment (QFD) to Optimally 
Identify and Prioritize the Needs ofHigher Education (case study: Engineering Faculty of Tarbiat Moallem University). Institute of Interdisciplinary Business Research

Prentice Hall. New Jersey
Kotler, Philip. 1988. Marketing Management: Analysis, Planning, Implementation, and Control. 